\title{
UREA IMPREGNATED BIOCHAR TO MINIMIZE NUTRIENTS LOSS IN PADDY SOILS
}

\author{
M.F. Dimin ${ }^{1 *}$, Sian-Meng Se ${ }^{1}$, Azizah Shaaban ${ }^{1}$ and M.M. Hashim ${ }^{2}$ \\ ${ }^{1}$ Department of Engineering Materials, Faculty of Manufacturing Engineering, \\ Universiti Teknikal Malaysia Melaka (UTeM), Hang Tuah Jaya, \\ 76100 Durian Tunggal Melaka, Malaysia \\ *Email: fairuz@utem.edu.my \\ Phone: +606-3316423; Fax: +606-331 6411 \\ ${ }^{2}$ Department of Land Management, Faculty of Agriculture, \\ Universiti Putra Malaysia
}

\begin{abstract}
Rubber wood sawdust (RWSD) is converted into a porous form of biochar through the slow pyrolysis process. In this study, it is used as a green binder to bind the urea together and form a fertilizer. The objective of the current research is to investigate the effect of biochar impregnation with urea on the $\mathrm{N}$-nutrients retention in soils. The biochars were produced at heating temperatures of $300{ }^{\circ} \mathrm{C}$ and $700{ }^{\circ} \mathrm{C}$ for 3 hours with continuous nitrogen gas purging at $30 \mathrm{ml} / \mathrm{min}$ and a constant heating rate of $5{ }^{\circ} \mathrm{C} / \mathrm{min}$. The obtained biochars were characterized by XRD, Boehm titration, $\mathrm{pH}$ alkalinity, BET specific surface area and SEM. Boehm titration demonstrated a reduction of acidic functional groups with the increase of heating temperature, recorded as 1.3 and 0.3 $\mathrm{mmol} / \mathrm{g}$ respectively for $300{ }^{\circ} \mathrm{C}$ and $700{ }^{\circ} \mathrm{C}$. Conversely, biochar produced at higher temperature was reported to have a larger specific surface area of $5.4 \mathrm{~m}^{2} / \mathrm{g}$. The impregnation was carried out on both biochars produced with molten urea. Results from mineralization showed that the sample with impregnation retained more nutrients in the soil compared to the un-impregnated sample, manifesting biochar as a potential material to be impregnated with urea for slow release and better nutrients retention in soil.
\end{abstract}

Keywords: Urea impregnated biochar, surface functional groups, mineralization, ammonium release, nitrate release.

\section{INTRODUCTION}

Biochar is a carbon-rich and stable form of charcoal obtained by thermal decomposition of biomass in a closed system with the absence of oxygen [1,2], and it can be applied to the soil for soil amendment and agronomic improvement. The physical and chemical properties of biochar such as high porosity and the presence of functional groups on its surface provide various advantages as a buffer to infertile soil [3]. The porous surface of biochar helps to increase the water-holding capacity and provides a habitat for microbial activities [4]. In addition, the surface function groups such as carboxylic, phenolic, lactone, pyranose, carbonyl and quinones improve the cation exchange capacity [5] and anion exchange capacity (AEC) for nutrient retention in the soil [6]. Urea is not an 'optimal fertilizer' in terms of plant nitrogen $(\mathrm{N})$ nutrition compared to calcium ammonium nitrate $\left[\mathrm{Ca}\left(\mathrm{NO}_{3}\right)_{2}\right]$ and ammonium nitrate $\left(\mathrm{NH}_{4} \mathrm{NO}_{3}\right)$, etc. However, it is widely used as $\mathrm{N}$ fertilizer, particularly in tropical countries. Worldwide, a total of 100.9 
million metric tonnes (Mt) of $\mathrm{N}$ was used in 2007/08, about 53.9 (approximately 53.4\%) in the form of urea [7]. This indicates that efficient management of urea is important and needs great attention. The reasons for the leading position of urea are due to its advantages of cost, handling and application. It has the lowest production cost and provides the highest $\mathrm{N}$ content (46\%). Moreover, there is no fire and explosion hazard. It is highly soluble in water and very hydroscopic. The main drawback of urea as $\mathrm{N}$ fertilizer is the large losses in the form of the gases ammonia $\left(\mathrm{NH}_{3}\right)$ and nitrogen dioxide $\left(\mathrm{NO}_{2}\right)$. Expressed in the percentage of $\mathrm{N}$ fertilizer applied, these losses can range from $20 \%$ to $60 \%$ and they happen usually at a $\mathrm{pH}$ above 7.0 [8]. Mineralization is a hydrolysis process in the soil where urea is converted to ammonium $\left(\mathrm{NH}_{4}{ }^{+}\right)$, and will then be oxidized to nitrites $\left(\mathrm{NO}_{2}^{-}\right)$and to nitrate $\left(\mathrm{NO}_{3}{ }^{-}\right)$by bacteria named nitrobacter. The process of conversion of $\mathrm{NH}_{4}{ }^{+}$to $\mathrm{NO}_{3}{ }^{-}$is also known as nitrification [9]. Collectively the processes are summarized in Figure 1.

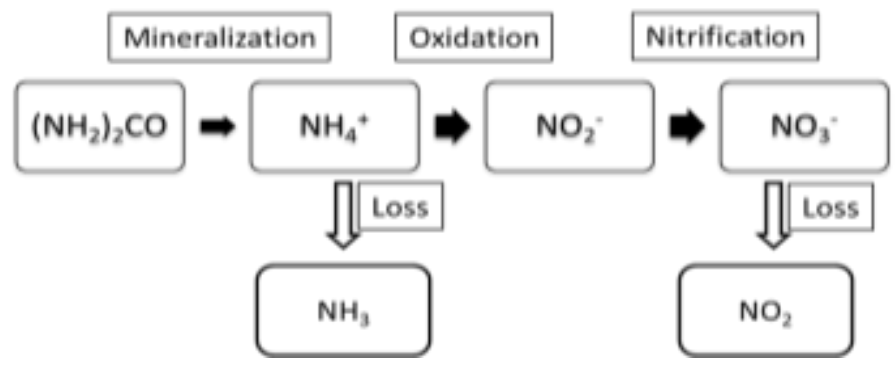

Figure 1. Mineralization and volatilation of nutrients.

The rate of mineralization is influenced by the temperature, soil $\mathrm{pH}$ and moisture of the soil. It is important to control the rate because fast conversion may cause the loss of nutrients by leaching and volatilation [8]. This phenomenon occurs when the plant is unable to absorb all the nutrients at one time because the nutrients are available in abundance, and this condition not only causes low nutrient use efficiency such that the fertilizer needs be applied more frequently, but also causes pollution of the environment such as the release of greenhouse gases and eutrophication [10]. Greenhouse gases such as ammonia $\left(\mathrm{NH}_{3}\right)$ and nitrogen dioxide $\left(\mathrm{NO}_{2}\right)$ are released by urea to the atmosphere, causing global warming. Leaching of $\mathrm{N}$ nutrient to the water by runoff of ground water or rain causes high nutrient content in water, which will encourage drastic plant growth in the water, with plants competing for space. The decomposition of dead plants consumes large amounts of oxygen from the water and so causes a low oxygen level in the water, making the water unsuitable for aquatic life. In addition, the maximum contaminant levels (MCL) for nitrate set by the World Health Organization (WHO) and US Environmental Protection Agency (EPA) for drinking water are set at 50 and $45 \mathrm{mg} / 1$ of $\mathrm{NO}_{3}$ respectively [11]. Elevated nitrate concentration in drinking water is linked to health problems such as methemoglobinemia (blue baby syndrome) in infants and stomach cancer in adults.

Applications of urea fertilizer need to be managed properly to minimize its sideeffects on humans and the environment. In the current approach, biochar synthesized from RWSD is introduced as the binder to bind with urea for the purpose of slowing down the mineralization and nitrification that contributes to leaching and volatilities. This compound would bring a dual benefit of decreasing the applied fertilizer requirements, as well as mitigating the environmental effects of nutrients loss. Reducing 
nutrient loss is valuable, as retained nutrients should equally remain available for plant growth and nutrient-use efficiency. Hence, the current research introduces the biocharurea impregnated fertilizer to retain more $\mathrm{N}$ nutrients $\left(\mathrm{NH}_{4}{ }^{+}\right.$and $\left.\mathrm{NO}_{3}{ }^{-}\right)$in soil, which can be achieved through physiochemical adsorption.

\section{MATERIALS AND METHODS}

\section{Pyrolysis of Biochar}

Rubber wood sawdust was collected from a sawmill in Melaka, Malaysia. It was sieved to remove the big lumps and dried at $105{ }^{\circ} \mathrm{C}$ for 24 hours [12]. Urea (AR Grade) was purchased from Polyscientific Enterprise Sdn. Bhd. Prior to the pyrolysis process, proximate analysis was performed on the raw RWSD by using TGA (Mettler Toledo Star SW901) under a nitrogen atmosphere with a gas flow rate of $10 \mathrm{ml} / \mathrm{min}$. The sample was heated from room temperature to $700{ }^{\circ} \mathrm{C}$ at a heating rate of $5{ }^{\circ} \mathrm{C} / \mathrm{min}$. Then, after a CHN elemental analyser (Therma Finnigan EA 1112) was used for ultimate analysis, the sample was prepared by grinding the dried raw RWSD into a smaller particle size and sieved to $20 \mu \mathrm{m}$ using a lab-scale milling machine. The pyrolysis process was carried out using a stainless steel vertical tube furnace $1.0 \mathrm{~cm}$ in diameter and $50.0 \mathrm{~cm}$ in length. Nitrogen gas was continuously purged into the furnace at a flow rate of $30 \mathrm{ml} / \mathrm{min}$ throughout the pyrolysis process. The heating rate was constant at $5{ }^{\circ} \mathrm{C} / \mathrm{min}$. Then, the heating temperatures were manipulated at $300{ }^{\circ} \mathrm{C}$ and $700{ }^{\circ} \mathrm{C}$ from room temperature for 3 hours holding time and they were then labelled as $\mathrm{BC} 300$ and $\mathrm{BC} 700$ [3].

\section{Characterization of Biochar}

The produced biochars were examined for X-ray diffraction (XRD) using a PANalytical X'Pert PRO MPD PW 3040/60 diffractometer using K $\alpha$ with a scan speed of $2.5^{\circ} \mathrm{min}^{-1}$ to determine the degree of crystallinity of the cellulose structures. Surface negative charge was determined using a titrimetric method based on Boehm to quantify the amount of acidic functional groups present [13]. Hydrogen ion concentrations of the samples were measured using a Fisher Scientific $\mathrm{pH}$ meter by mixing charcoal with deionized water in a ratio of 1:20, and the mixture was shaken for 5 minutes before the test. A Micromeritics ASAP 2010 was used for Brunauer-Emmett-Teller (BET) surface area analysis by an automated nitrogen multilayer absorption system. A scanning electron Microscope (SEM) (Zeiss Evo 50) was used for surface morphology analysis.

\section{Preparation and Characterization of Urea Impregnated Biochar}

Molten urea was prepared by dissolving the urea granules in water with continued heating at approximately $70{ }^{\circ} \mathrm{C}$ using a magnetic hot plate with stirring. Prepared biochars were added during stirring and heating with $2 \mathrm{wt}$. $\%$ of biochar. The stirring process was held for 1 hour at a constant temperature of $70{ }^{\circ} \mathrm{C}$, the composites were labelled as UBC 300 and UBC 700, and they were then stored in a conventional oven at $60{ }^{\circ} \mathrm{C}$ for 24 hours [14]. Surface functional groups were determined by Fourier Transform Infrared (FT-IR), and the test specimens were prepared by mixing the charcoal with $\mathrm{KBr}$ at a fixed ratio to fabricate a translucent disc and the spectrum scope was in the range of $400 \mathrm{~cm}^{-1}$ to $4000 \mathrm{~cm}^{-1}$ with a resolution factor of $4 \mathrm{~cm}^{-1}$. 


\section{Mineralization Test and Determination of Ammonium and Nitrate Content}

$20.0 \mathrm{~g}$ of paddy soil from the paddy field was added to $25.0 \mathrm{ml}$ of distilled water and $400 \mu \mathrm{g}$ of urea-impregnated biochar samples, the composition was mixed well, and put in a plastic container for the mineralization process. Approximately $2.0 \mathrm{~g}$ of the soil sample was taken from the container for determination of the mineralization rate, at intervals of week 1, week 2 and week 3. The soil sample was added to potassium chloride-phenylmercuric acetate (KCl-PMA) solution and shaken for 1 hour, for determination of the ammonium content, and was then distilled with $0.5 \mathrm{~g}$ of magnesium oxide $(\mathrm{MgO})$ with $2.0 \%$ boric acid, then titrated with $0.1 \mathrm{~N} \mathrm{HCl}$. Similar steps were carried out for nitrate determination but Devarda's alloy was added to the mixture for distillation with $\mathrm{MgO}$.

\section{RESULTS AND DISCUSSION}

\section{Characterization of Raw RWSD}

From proximate and ultimate analysis of RWSD and previous work reported by other researches as shown in Table 1, it was found that the ash content, volatile matter and moisture content are comparable to the data published by previous researchers. Moisture content is determined by the weight lost at a temperature of $120{ }^{\circ} \mathrm{C}$, where the water was released in the form of vapour through dehydration. The fixed carbon content was relatively high compared to the published data, which may be attributed to the fact that the volatilation of weight loss at temperatures between $150{ }^{\circ} \mathrm{C}$ and $450{ }^{\circ} \mathrm{C}$ was lower for the RWSD. This indicates that RWSD is a suitable candidate for biochar production.

Table 1. Proximate and ultimate analysis of RWSD.

\begin{tabular}{lccccccc}
\hline & \multicolumn{4}{c}{ Proximate analysis (\%) } & \multicolumn{3}{c}{ Ultimate analysis (\%) } \\
\hline Sample & $\begin{array}{l}\text { Ash } \\
\text { content }\end{array}$ & $\begin{array}{l}\text { Volatile } \\
\text { matter }\end{array}$ & $\begin{array}{l}\text { Moisture } \\
\text { content }\end{array}$ & $\begin{array}{l}\text { Fixed carbon } \\
\text { content }\end{array}$ & Carbon & Hydrogen & Nitrogen \\
\hline RWSD & 2.26 & 70.78 & 2.52 & 24.44 & 43.27 & 6.83 & 0.39 \\
\hline$[13,14]$ & $0.34-4.88$ & $68.9-82.5$ & $1.69-9.40$ & $9.30-19.30$ & $\begin{array}{c}43.15- \\
50.4\end{array}$ & $5.49-6.35$ & $0.02-1.68$ \\
\hline
\end{tabular}

\section{Characterization of Biochar}

\section{Phase Analysis by XRD}

An XRD diffractogram is usually used to study the crystallinity of a material and Figure 2 shows the diffratogram for the raw RWSD and biochar samples. RWSD is a biomass cellulosic material that consists of cellulose, hemicellulose and lignin. For native cellulose materials, two peaks will be detected at (i) a high intensity peak at $2 \theta$ angle between $22-24^{\circ}$ for crystallinity of cellulose and (ii) an amorphous peak in intensity of a $2 \theta$ angle around $16^{\circ}$ [15]. The raw RWSD diffractogram showed two broad peaks at $2 \theta$ angles $=15.5^{\circ}$ and $22.1^{\circ}$, demonstrating the presence of cellulose crystallinity, and a similar trend was reported by Wang, Cao [16] . After heating at 300 ${ }^{\circ} \mathrm{C}$ for 3 hours, the crystallinity peak was shifted to $24.4^{\circ}$, as shown in BC 300 , and 
disappeared with the increase of temperature for BC 700. This may indicate the effect of temperature on the crystal structure of cellulose and decomposition of cellulose crystalline at higher temperatures [15].

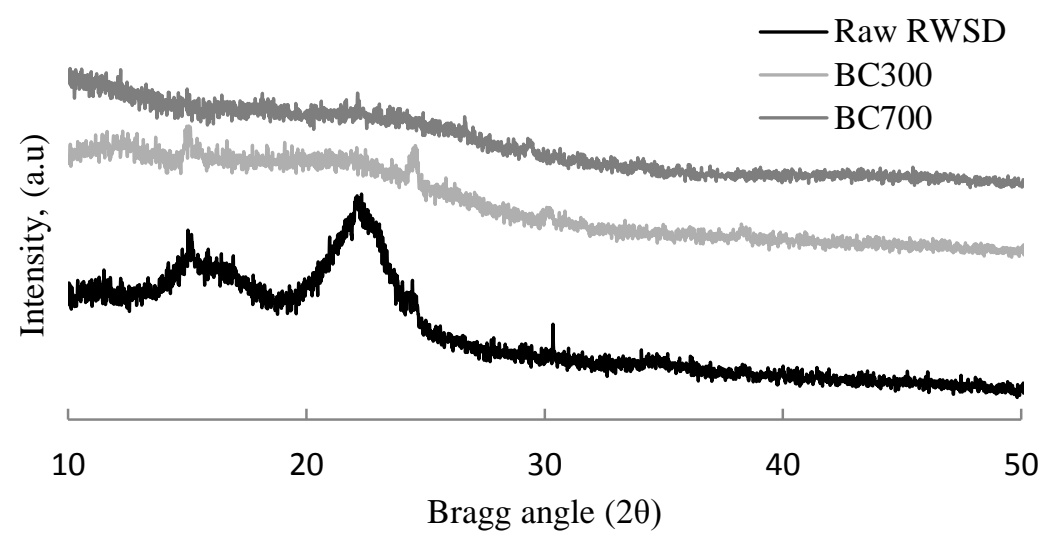

Figure 2. XRD diffractogram for raw RWSD and biochar samples.

\section{Surface Functional Groups and Porosities of Biochars}

Table 2 displays the surface functional groups and surface porosities for the biochar samples. The surface negative charge indicates the presence of acidic groups such as carboxylic acid, phenolic and lactone. It was found that the surface negative charge reduced from $1.30 \mathrm{mmol} / \mathrm{g}$ to $0.30 \mathrm{mmol} / \mathrm{g}$ with the increase of pyrolysis temperatures, which may be due to the volatilities and gasification of acidic groups to form gases such as carbon dioxide, methane, etc. at higher temperatures. Inversely, the $\mathrm{pH}$ of biochars increased with the pyrolysis temperature from $\mathrm{pH} 7.67$ and 11.67 for $\mathrm{BC} 300$ and $\mathrm{BC}$ 700 , respectively. This phenomenon may be due to the reduction of acidic groups and formation of basic groups such as pyranose, carbonyl and quinones due to progressive carbonization. The BET specific surface area increased with the heating temperature from $1.93 \mathrm{~m}^{2} / \mathrm{g}$ to $5.49 \mathrm{~m}^{2} / \mathrm{g}$ for BC 300 and BC 700, respectively. In addition, the BC 700 has a larger external surface area, micropore volume and total volume in pores compared to BC 300, which might be explained by the effect of temperature in increasing the creation of new pores [17]. This is supported by the SEM micrographs as shown in Figure 3(b) and 3(c), where more pores with smaller sizes were developed at the higher temperature for sample BC 700. These two properties are important for the impregnation with urea on the release of nutrient when applied to paddy soils [6]. The heating temperature has a significant effect on the physiochemical properties of the biochars; at higher temperature more pores developed but the surface functional groups reduced.

Table 2. Surface functional groups and surface porosities of biochar samples.

\begin{tabular}{ccccccc}
\hline Sample & \multicolumn{2}{c}{ Surface functional groups } & \multicolumn{3}{c}{ Surface porosities } \\
\hline & $\begin{array}{c}\text { Surface } \\
\text { negative } \\
\text { charge } \\
(\mathrm{mmol} / \mathrm{g})\end{array}$ & $\mathrm{pH}$ & $\begin{array}{c}\text { BET } \\
\text { surface } \\
\text { area }\left(\mathrm{m}^{2} / \mathrm{g}\right)\end{array}$ & $\begin{array}{c}\text { External } \\
\text { surface } \\
\text { area }\left(\mathrm{m}^{2} / \mathrm{g}\right)\end{array}$ & $\begin{array}{c}\text { Micropore } \\
\text { volume } \\
\left(\mathrm{x} 10^{-6}\right. \\
\left.\mathrm{cm}^{3} / \mathrm{g}\right)\end{array}$ & $\begin{array}{c}\text { Total } \\
\text { volume in } \\
\text { pore }\left(\mathrm{x} 10^{-3}\right. \\
\left.\mathrm{cm}^{3} / \mathrm{g}\right)\end{array}$ \\
\hline BC 300 & 1.30 & 7.67 & 1.93 & 2.20 & 0.00 & 4.00 \\
BC 700 & 0.30 & 11.67 & 5.49 & 3.33 & 950.00 & 10.46 \\
\hline
\end{tabular}




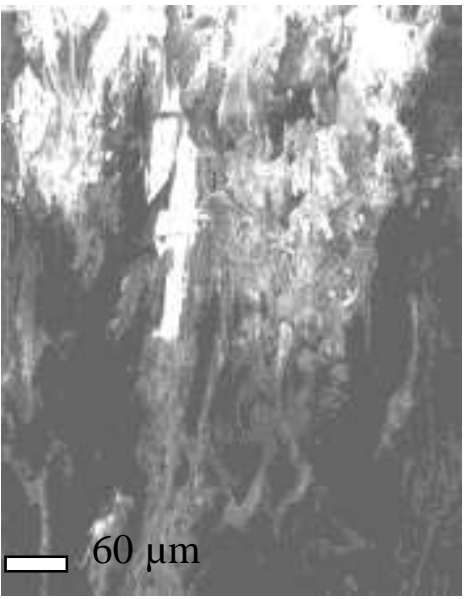

(a)

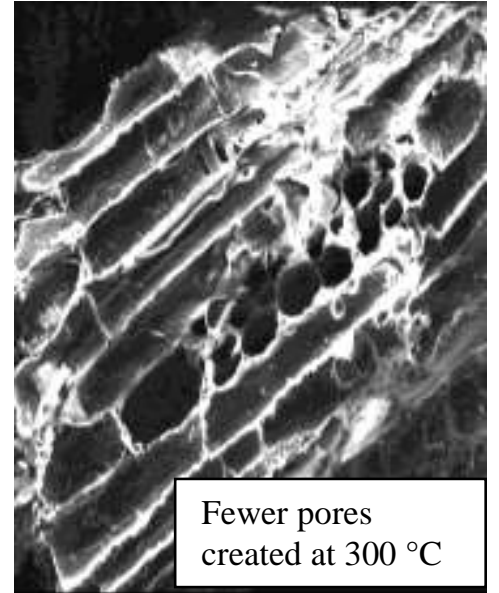

(b)

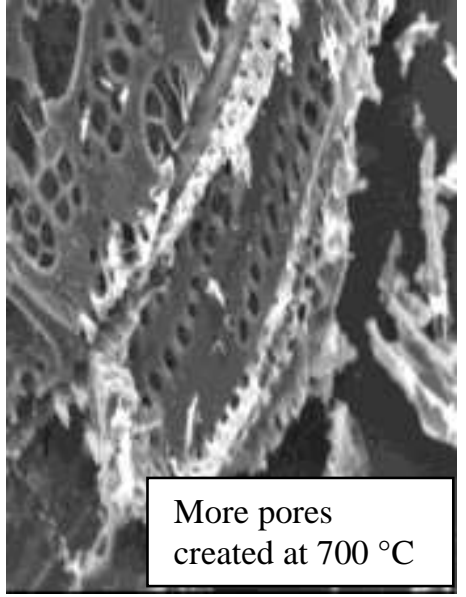

(c)

Figure 3. SEM micrograph of (a) raw RWSD (b) BC 300 and (c) BC 700.

\section{Characterization of Urea-impregnated Charcoal}

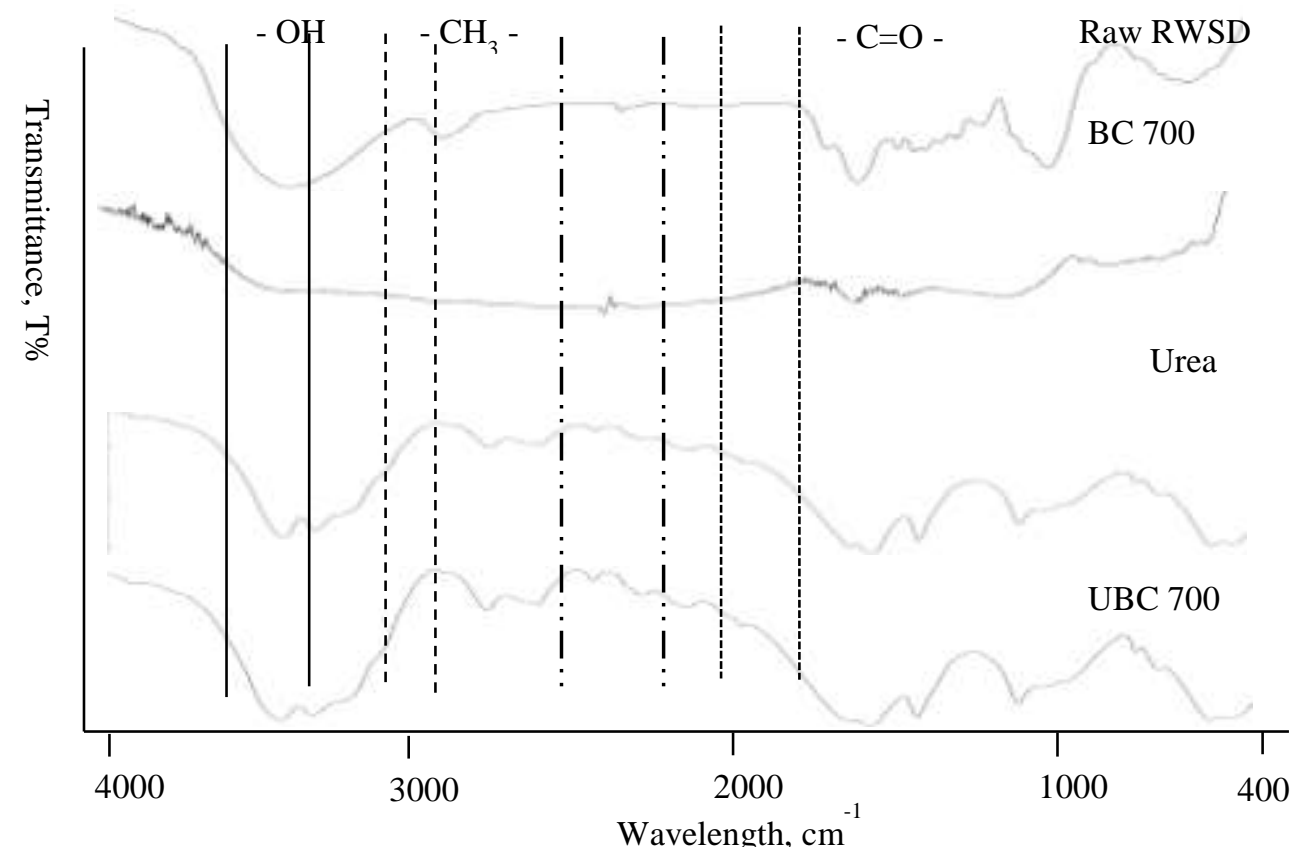

Figure 4. FT-IR spectra of raw RWSD, BC 700, Urea UBC 700.

Figure 4 displays the FT-IR spectra for raw RWSD, BC 700, urea and UBC 700. The spectra of raw RWSD and BC 700 showed that some of the functional groups in RWSD have disappeared after heating at $700{ }^{\circ} \mathrm{C}$ for 3 hours. The spectrum becomes more simple at high temperature, which may be due to the volatilities and decomposition of functional groups especially acid groups such as $-\mathrm{OH}$ at the wave number range of 3550-3394 $\mathrm{cm}^{-1}$. The methylene group from cellulose was decomposed due to the disappearance of $-\mathrm{CH}_{3}$ - for $\mathrm{BC} 700$ at a wavelength around 3000 $\mathrm{cm}^{-1}$. This shows good agreement with the low surface negative charge of the biochar sample produced at high temperature, $\mathrm{BC} 700$, as in Table 2. The spectra pattern for 
urea and UBC 700 are similar to each other. However, it is worth noting that at a wavelength of approximately $2500 \mathrm{~cm}^{-1}$ the UBC 700 sample showed sharper and more obvious peaks, indicating the carboxylic $\left(-\mathrm{COO}^{-}---\mathrm{H}^{+}\right)$bonding formed through the impregnation between urea and biochar [18].

\section{Mineralization of Urea-N into $\mathrm{NH}_{4}{ }^{+}$and $\mathrm{NO}_{3}{ }^{-}$in Soil}

Figure 5 shows ammonium $\left(\mathrm{NH}_{4}{ }^{+}\right)$and nitrate $\left(\mathrm{NO}_{3}{ }^{-}\right)$retained in the paddy soil for week 1 , week 2 and week 3 . It was found that standard urea has a higher gradient of the slope of the linear plot compared to UBC 300 and UBC 700, at -73.43 compared to 64.67 and -71.76 respectively. This indicates that the release of $\mathrm{NH}_{4}{ }^{+}$and $\mathrm{NO}_{3}{ }^{-}$through mineralization and nitrification of the urea was faster than the impregnated samples in the paddy soil. In addition, the gradient of UBC 300 is lower than UBC 700, which demonstrates the slower release of nutrient into the soil for UBC 300. Furthermore, it is worth mentioning that the samples UBC 300 and UBC 700 retained more $\mathrm{NH}_{4}{ }^{+}$and $\mathrm{NO}_{3}{ }^{+}$in the soil after week 1 , week 2 and week 3 compared to the urea. This demonstrates that the volalities of urea have been reduced through impregnation and the loss of nitrogen compound to greenhouse gases such as $\mathrm{NH}_{3}$ and $\mathrm{NO}_{2}$ has diminished. It was also observed that UBC 300 retained higher nutrients compared to UBC 700 throughout the study, which might be due to the surface negative charge from acidic functional groups on BC 300 being greater than BC 700, as shown in Table 2. The surface negative charge on biochar $\left(-\mathrm{O}^{-}\right)$from carboxylic and phenolic groups may have the ability to attract positive ions in soils such as $\mathrm{NH}_{4}{ }^{+}$to its surface, which might improve the soil's cation-holding capacity. Therefore, $\mathrm{BC} 300$ is able to hold the $\mathrm{NH}_{4}{ }^{+}$ in the soil and prevent it from converting to $\mathrm{NH}_{3}$.

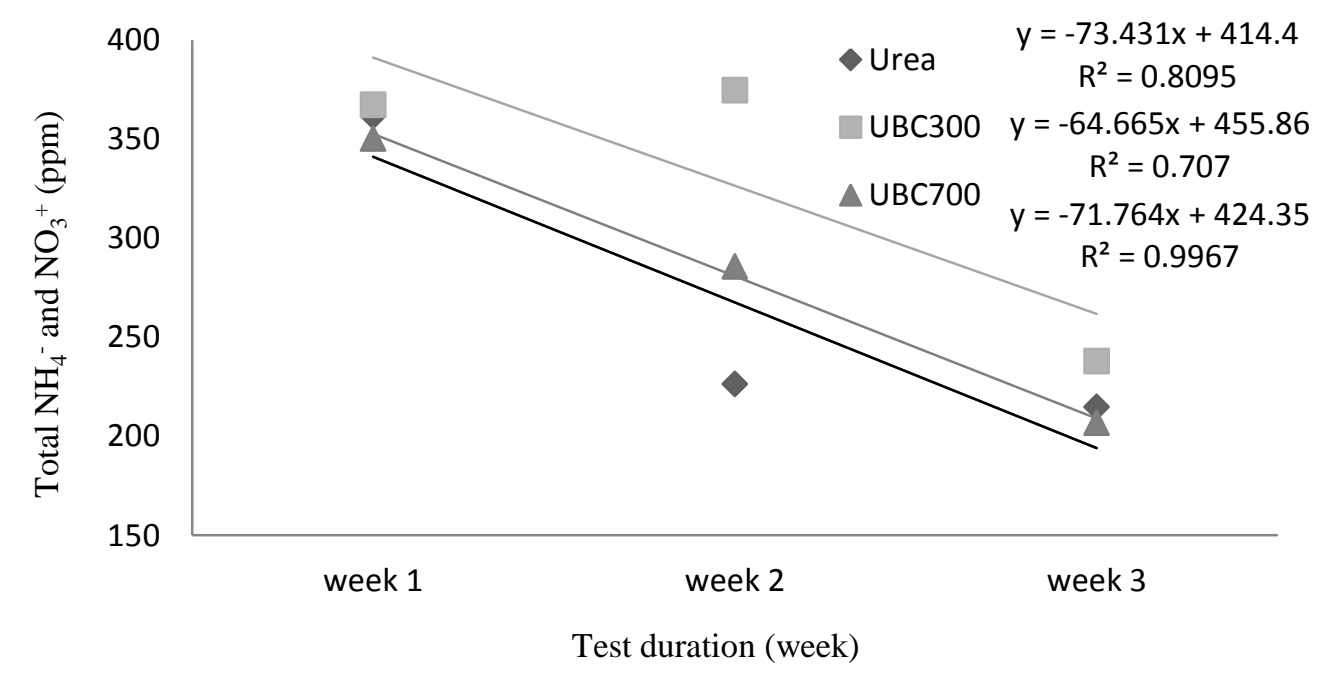

Figure 5. Ammonium $\left(\mathrm{NH}_{4}{ }^{+}\right)$and nitrate $\left(\mathrm{NO}_{3}{ }^{-}\right)$remaining in paddy soil for week 1 , week 2 and week 3 .

\section{CONCLUSIONS}

In the current work, RWSD was converted into biochar and was used as a binder to produce green urea-impregnated biochar fertilizers. The nutrient retention for the fertilizer samples in paddy soil was studied. The mineralization of urea in the impregnation samples was found to be slower than the standard urea sample. Moreover, 
the sample UBC 300 retained more nutrients in paddy soil compared to UBC 700. This demonstrated that biochar produced at a lower pyrolysis temperature possesses a greater surface negative charge compared to higher temperature pyrolysis, and the existence of the surface negative charge helped to improve the cation-holding capacity. Thus, cations such as $\mathrm{NH}_{4}{ }^{+}$available in the soil will attach to the negative surface charge on the biochar. Urea-impregnated biochar fertilizer is a doubly green fertilizer because it helps to reduce the volatilation of $\mathrm{NH}_{3}$ and $\mathrm{NO}_{2}$ to the atmosphere and increases the carbon storage in soil, known as sequestration.

\section{ACKNOWLEDGEMENTS}

The authors are very thankful to the Faculty of Manufacturing Engineering and Faculty of Mechanical Engineering, Universiti Teknikal Malaysia Melaka (UTeM) for providing the facilities and constant encouragement. The authors would also like to acknowledge funding from Long Term Research Grant Scheme (LRGS) under LRGS/2011/FKP/TK02/1 R0000 and Ministry of Higher Education (MOHE) under My Brain 15.

\section{REFERENCES}

[1] Freddo A, Cai C, Reid BJ. Environmental contextualisation of potential toxic elements and polycyclic aromatic hydrocarbons in biochar. Environmental Pollution. 2012;171:18-24.

[2] Mohamad N, Nor Nadiah AH, Jeefferie AR, Mohd Fairuz D. Effect of Chitosan gelatinization temperature on water absorption and water retention of chitosanbased urea fertilizer. International Journal of Automotive and Mechanical Engineering. 2013;8:1357-66.

[3] Shaaban AaS, Sian Meng and Mohd Fairuz, Dimin and Hamid, Nadiah. Slow Pyrolysis And Characterization Of Surface Functional Groups For Biochar Derived From Rubber Wood Sawdust. International conference on mechanical engineering research. Gambang, Malaysia: Universiti Malaysia Pahang; 2013.

[4] Atkinson CJ, Fitzgerald JD, Hipps NA. Potential mechanisms for achieving agricultural benefits from biochar application to temperate soils: a review. Plant and soil. 2010;337:1-18.

[5] Rao RR, Peterson AW, Ceccarelli J, Putnam AJ, Stegemann JP. Matrix composition regulates three-dimensional network formation by endothelial cells and mesenchymal stem cells in collagen/fibrin materials. Angiogenesis. 2012;15:253-64.

[6] Sohi S, Krull E, Lopez-Capel E, Bol R. A review of biochar and its use and function in soil. Advances in agronomy. 2010;105:47-82.

[7] Association IFI. IFADATA statistics Production, imports, exports and consumption data for nitrogen, phosphate and potash 1973/74 to 2007/08. Paris, France: International Industry Association; 2010.

[8] Trenkel ME. Slow-and controlled-release and stabilized fertilizers: An option for enhancing nutrient use efficiency in agriculture: IFA, International fertilizer industry association; 2010.

[9] Amberger A, Association IFI. Soil fertility and plant nutrition in the tropics and subtropics. Paris, France: IFA, International Fertilizer Industry Association; 2006. 
[10] Frye W. Nitrification inhibition for nitrogen efficiency and environment protection. IFA International Workshop on Enhanced-Efficiency Fertilizers June. Frankfurt: IFA International Workshop on Enhanced-Efficiency Fertilizers; 2005. p. 28-30.

[11] Organization WH. International statistical classification of diseases and related health problems: World Health Organization; 2004.

[12] Se SM, Shaaban A, Ibrahim IM. Microwave absorbing material using rubber wood sawdust. Wireless Technology and Applications (ISWTA), 2011 IEEE Symposium on. Langkawi, Malaysia: IEEE; 2011. p. 192-7.

[13] Novak JM, Lima I, Xing B, Gaskin JW, Steiner C, Das K, et al. Characterization of designer biochar produced at different temperatures and their effects on a loamy sand. Annals of Environmental Science. 2009;3:2.

[14] Khan MA, Kim K-W, Mingzhi W, Lim B-K, Lee W-H, Lee J-Y. Nutrientimpregnated charcoal: an environmentally friendly slow-release fertilizer. The Environmentalist. 2008;28:231-5.

[15] Nazir MS, Wahjoedi BA, Yussof AW, Abdullah MA. Eco-friendly extraction and characterization of cellulose from oil palm empty fruit bunches. BioResources. 2013;8:2161-72.

[16] Wang Z, Cao J, Wang J. Pyrolytic characteristics of pine wood in a slowly heating and gas sweeping fixed-bed reactor. Journal of Analytical and Applied Pyrolysis. 2009;84:179-84.

[17] A S, Se S-M, Dimin M, Juoi JM, Mohd Husin MH, Mitan NMM. Influence of heating temperature and holding time on biochars derived from rubber wood sawdust via slow pyrolysis. Journal of Analytical and Applied Pyrolysis. 2014;107:31-9.

[18] Ahmad A, Loh M, Aziz J. Preparation and characterization of activated carbon from oil palm wood and its evaluation on methylene blue adsorption. Dyes and Pigments. 2007;75:263-72. 